\title{
Aquaculture Industry in Odisha: A Review
}

Brajaballav Kar ${ }^{+*}$ and Sugato Tripathy ${ }^{*}$

\section{Abstract}

Odisha's economy is predominantly agriculture driven. Exports from mining industries remained a significant source of foreign exchange. However, over a period, aquaculture exports have also emerged as a lucrative possibility. It is a perfectly suitable sector considering the long coastline, rivers and water bodies and labour intensive nature of the industry. From an individual or community level of operation, aquaculture developed the characteristics of industry in the early 1970s.

This descriptive research paper investigates the history of the aquaculture industry in Odisha over the past 50 years. The aquaculture industry in Odisha started two decades later than Kerala (another southern state of India), in the form of an experiential learning and opportunity-seeking process by the early players. The subsequent dominance of local players, consolidation, and expansion of the export market proves the natural resource advantage of the State.

The study emphasises the contribution of the sector to the state economy. The adoption of healthy consumption habits, large untapped Indian market, value and values-addition in the product, and evolving traceability requirements for exports are some of the significant challenges facing the industry.

Despite being an important sector for the State, this sector has not received due attention from academic research. Technology adoption practices, productivity improvement, internal competitions, development of industry structure, and role of policy could be some areas for future research.

Keywords: Aquaculture; Industry Review; History; Secondary Research; Odisha

\footnotetext{
${ }^{+}$KIIT University, India

${ }^{*}$ Corresponding Author, Email: brajkar@gmail.com

${ }^{\sharp}$ KIIT University, India, Email: sugatotripathy@ksom.ac.in

(C) 2020 Kar \& Tripathy. This is an Open Access article distributed under the terms of the Creative Commons Attribution License (http://creativecommons.org/licenses/by/2.0), which permits unrestricted use, distribution, and reproduction in any medium, provided the original work is properly cited.
} 


\section{Introduction}

The seafood export industry in India began when the first shipment of frozen shrimp was sent from the port of Cochin in 1953 by Mr. Madhavan Nair, the owner of Cochin Company. The non-availability of cans hindered canned shrimp exports, and instead, the exports of frozen shrimps became prevalent. The export of other varieties of fish started later in the late 1960s (History, Seafood Exporters Association of India, n.d.).

After China, India is the second-largest fish producer accounting for around six per cent of global fish production. Indian fisheries employ close to 15 million people and earn substantial foreign exchange through export. The share of marine product exports has steadily grown from USD 600000 in 1961-62 to USD 1.1 billion in 2005-06; the export was USD 5.78 billion in the financial year 2017 (Dasgupta, 2018).

In Odisha, about 4 per cent population depends upon fisheries for their livelihood. Of the total 1.69 million, 0.89 million depend on inland and 0.81 million on marine fisheries. This sub-sector contributed about 6 per cent to the gross state domestic product share of the agriculture sector during 2012-13 (APICOL, n.d.)

Freshwater resources of the state are estimated to be 0.68 million hectare (ha) comprising of tanks, ponds, reservoirs, lakes, swamps, rivers and canals. The state's brackish water resources are of the order of 0.42 ha comprising of Chilika Lake, estuaries, brackish water area and backwaters (Odisha Fisheries Policy, 2015, 2015).

The overall annual growth rate of production was about 3 per cent during the period 2007-08 to 2012-13, whereas, the CAGR during the period 2008-09 to 2017-18 was about 7 per cent (India - fish production volume in Odisha 2018, n.d.). The annual per capita fish consumption during 2015 was $9.13 \mathrm{~kg}$ in Odisha, which is less when compared to the national average of 9.8 $\mathrm{kg}$. The fisheries policy of the state proposes different developmental activities for the growth in production (Odisha Fisheries Policy, 2015, 2015).

This viewpoint draws upon interviews conducted with aquaculture business owners and fishers in Odisha. Three interviews were conducted with senior members of Seafood Exporters Association of Odisha in Odia language. Interviews were recorded, English transcription was prepared, and verified with interviewees. The historical narratives of the industry are derived from the interviews and subsequently corroborated with available secondary data from various sources. The study begins with a brief history of Aquaculture in Odisha followed by the challenges and the contribution of aquaculture to the state of Odisha.

\section{History of Aquaculture in Odisha}

\section{The 1970s - The Start}

Before the 1970s, fisheries and related business were for local consumption only; there was no export by the local players. Britania, Union Carbide and Spencer were three large companies that purchased catch from local fishers, processed further and exported.

During the early 1970s, a new company, $\mathrm{Cl}$ Foods Limited started its operation in Odisha. Along with it, three other units also started their operations in Puri district. These plants had low capacity, and they sold to Britania after initial processing. During 1975-77, many new companies, including George Maijo, Puri Marine, Orissa Marine, started operations in Odisha. A Seafood Association was formed. Few of these companies started exporting independently. In subsequent years, almost all the companies started exporting.

\section{The 1980s: Industry Shakeup and Consolidation}

As the competitors increased, the number of trawlers in Paradeep port area increased too. People in business started venturing to other places like Balasore, Balramgadi, Astarang and others. The catch from the sea was good. The efficiency factors such as cost of production became vital with the competition. During the 
1980s, around INR 0.5 million for working capital was sufficient to export INR 50 million worth of products.

Japan was the major importer; Paradeep Port was the hub of export activities. The export payment terms were favourable (sans any delay). The exporters did not need large working capital. Other countries used to import from South India. Sensing the growth and opportunity, entrepreneurs from Odisha, as well as non-resident Odias entered the market. The large companies had massive operations, professionals, and overheads, compared to local companies and faced challenges to maintain product quality, price, and cost. The local businesses could strike the right chord with suppliers and intermediaries; understood the market better through relationship and dialect advantage. The channel conflicts reduced, and the negotiation was favourable with various stakeholders. The larger companies from outside the state could not sustain and quit from their businesses. By 1987-88, only a few non-local (George Maijo and Puri Marine) businesses continued along with the local ones. Suitable land was available; plant and machinery were easily acquired by new players with the exit of the incumbent ones.

The Food and Agricultural Organisation (FAO, UN) Report is an accurate, publicly available report indicating the status during the 1980s and before, on fisheries in Odisha (Tietze, 1991). The report documents that the marine fisheries sector was showing steady growth in terms of the number of mechanised and non-mechanised boats, ice plants, and freezing plants. Till 1979, the marine catch showed favourable growth but stagnated subsequently.

Twenty-nine primary fishermen cooperative societies (PFCS) were functioning, and the majority were in and around the Chilika lake. Gangadevi PFCS was the oldest recorded with the date of establishment as on 21 May 1958. By 1980 , synthetic twine had replaced cotton twine and nets were factory-made rather than handmade (Tietze, 1991).

The important landing centres for mechanised boats were in Talsari, Kirtania, Chudamani, Kasafal, Bidaipur, Chandinipal, Chandipur, Dhamara, Talchua, Paradeep, Astrang, and Rushikuliya. The export to Japan has been documented in the year 1978-79. There was growth in exports from 1978-79 to 1982-83.

Most of the organisations started as ice plants/cold storage units during the 1970s. A few names mentioned in the report are Orissa Marine, Puri Marine, Bijaya Marine, George Maijo Export, Sealords \& Seafood, Cl Foods, Surya Udyog, and Golden Dragon. There were 52 registered ice factories of the period, of which only five belonged to the public sector. All the 11 freezing plants belonged to the private sector. Puri Marine, $\mathrm{Cl}$ Foods, Sealands Seafoods, Golden Dragons, Surya Udyog, and Orissa Marine, are the freezing plants mentioned in the report. This indicates that few ice plants had freezing units.

Another report of the Central Marine Fisheries Research Institute, Cochin indicates the district wise species of fish caught over a period of 19751984 (Scariah, Philipose, Dan, Nair, \& Subbaraman, 1987).

\section{Current Status}

The date of incorporation and the status of the companies were ascertained to understand business continuity. The data is presented in Table 1 


\begin{tabular}{|c|c|c|}
\hline \multicolumn{3}{|c|}{ Table 1: Status of Seafood Exporters from Orissa } \\
\hline SI. & Name of the Exporter (M/s) & Date of Incorporation/ Status \\
\hline 1 & SuryoUdyog Limited & $23-09-1978$ \\
\hline 2 & Falcon Marine Exports & 03-07-1986 \\
\hline 3 & Ram Assorted Cold Storage & 26-05-1986 \\
\hline 4 & Magnum Seafoods & 02-11-1987 \\
\hline 5 & Suryo Foods \& Industries & 12-05-1989 \\
\hline 6 & Bijaya Marine Products & 24-01-1992 \\
\hline 7 & Rayson's Aquatic & 23-03-1994 \\
\hline 8 & Seagold Overseas & 13-12-1994 \\
\hline 9 & Sealand Fisheries & 11-11-1994, Struck-off \\
\hline 10 & Noble Aqua & $15-12-1995$ \\
\hline 11 & Konark Aquatics Exporters & 19-07-1995 \\
\hline 12 & ShyamSundar Marine Export & 29-11-1999 \\
\hline 13 & Teekay Marine & 17-04-2001 \\
\hline 14 & Dhamarai Marine Exports & 02-06-2004, Struck-off \\
\hline 15 & Chanchala Combines & $13-04-2004$ \\
\hline 16 & Odyssa Exim. House Pvt. Ltd. & 17-02-2004, Struck-off \\
\hline 17 & Sri Jaganath Export \& Import & The date could not be ascertained, as it is \\
\hline 18 & Mahabir Exports & not publicly available or not limited \\
\hline 19 & Padmasa International & companies. \\
\hline 20 & Sun Impex & \\
\hline 21 & Fabri Food Products & \\
\hline 22 & Laxmi Enterprises & \\
\hline 23 & AdityaUdyog & \\
\hline
\end{tabular}

\section{The 1990s: Tiger Prawn to Vannamei}

Up to 1990, the primary source of prawn and fish was the sea. Odisha with a coastline of 480 kilometres with proximity to many Asian and South East Asian nations was ideal for marine export.

\section{Black Tiger Prawn}

Earlier, Black Tiger prawn (BT) was available from Chilika lake and other estuaries with similar eco-systems. With the growth in demand, almost every player acquired land to set up the infrastructure for aquaculture. Cultivation of BT prawn gave rise to an aquaculture boom during the 1990s. It could ensure an uninterrupted supply.

Initial productivity was 9-10 tons per hectare. When production increased subsequently, people in business started planning for additional factories. During 1992, Surya Foods raised capital from the primary market for expansion.

Towards the end of 1992, the business suffered an unseen setback. The production became infected due to a virus attack and prawn farming became unsustainable within $4-5$ years. The infection made the ponds unusable completely disrupting the production cycle. Many business people incurred heavy losses and quit the business. They either abandoned or disposed of the BT prawn business.

\section{Vannamei Culture}

The Vannamei species prawns were more resistant to the virus attack and more sustainable, which proved to be a boon for aquaculture business. The business of BT prawns reduced substantially as companies shifted towards Vannamei. The prawn price is dependent on the size, and the difference 
between the two types was negligible. Though BT prawn is priced a few cents higher, after beheading, the average weight of Vannamei is a few grams more. The Vannamei also has 0.5 months less gestation period compared to BT prawns (3.5 months). The harvest quantity for Vannamei was 3-4 times as compared to BT Prawn.

However, Odisha adopted Vannamei culture only after it proved successful in Andhra Pradesh, albeit there were initial apprehensions after a disastrous loss and suffer in BT prawns. The wait was to check the sustainability of the business. An average hatchery production varied from 15-50 million hatches in 15 days.

The aquaculture market needed its supporting systems. The fish and prawn feed is the ancillary sector for aquaculture.

\section{The Fish and Prawn Feed Market}

The fish and prawn feed market in India was at USD 1.7 billion in 2017 and estimated to be USD 2.3 billion in sales by 2023 , posting a growth of 10.44 per cent per annum (India Aquaculture Feed Market Growth, Trends, and Forecast (2018-2023), n.d.). With 108 fish seed hatcheries and a production capacity of 673 million, there is enormous potential for the feed market in Odisha.

Andhra Pradesh accounts for 60000 tons of feed sale per month (the highest in the country). Other states with much lesser numbers follow it. The feed depends on the type of prawn - BT or Vannamei. Many companies in Odisha, including the ones in aquaculture, distribute the fish feed product. The market is competitive. The feed sale is a credit market. After the harvest period of 90-100 days, the farmers sell the product and then pay money for the feed. The credit period thus becomes $90-100$ days. At times, there is a risk of farmers reneging on payments. To avoid this, companies take post-dated cheques. The feed sale operates like a small bank where business people give credit to farmers and eventually recover from them. The process operates through a vast network.

\section{Domestic Market}

The domestic market demand is met by the unorganised sector and from Andhra Pradesh. Aquaculture firms are 100\% export-oriented units (EOUs) and cannot sell in the local market. The demand and price are also significantly less. However, the domestic market has to improve for the companies to be sustainable. Surprisingly, even being a coastal state, the annual per capita consumption of fish was 13.27 $\mathrm{kg}$ in 2008-09 and $9.13 \mathrm{~kg}$ in 2012-13 showing a contrarian trend (Fisheries and Animal Resources Development Department, 2014). The increased risk of many chronic diseases due to the consumption of red meat should imply higher fish and prawn consumption (Wolk, 2017). The North Indian market has a higher consumption of red meat but, the trend is shifting to healthier lifestyles, and gradual closure of slaughterhouses should increase fish and shrimp consumption providing a vast and stable market for aquaculture in India.

\section{Prawn Culture and Export Market}

The domestic market in India is not large. The coastal states are major producers and consumers, and prawn consumption is not widespread in North India. Initially, the primary market for shrimps was Europe. The Chinese are pioneers of Vannamei culture and are the largest exporter. In the case of BT prawn, business people used to get the male-female pair from the sea and use them for hatching in the hatcheries. However, in the case of Vannamei, the USA firms have the patent, and the farmers used to buy from them. Even the Chinese imports the breed from the USA. India has a research institute in Chennai (Central Institute of Brackishwater Aquaculture), and some success in this direction has been achieved. The confidence in Indian brood is a little less compared to imported ones. Due to the current restriction in import from the USA, it is imported from Indonesia and Thailand. These broods are comparatively better. One male-female pair hatches about ten times. The first 2 to 3 hatchings are not as desired and thus have to be drained out. From the third or fourth time, it is used for commercial purposes. In the Vannamei 
culture, countries like China, Thailand, and Indonesia have a leading presence. The Global Aquaculture Alliance report (2019) indicates that shrimp production has increased substantially over the period (Anderson, Valderrama, \& Jorry, n.d.). The global price keeps fluctuating.

Interestingly, China has started importing Vannamei from India. Their production is not sufficient to meet their increasing internal consumption. The soil condition of the pond also degrades after many years of culture.

The European Union (EU) prohibits the presence of antibiotics traces in prawns. The exporter always faces the risk of rejection and loss. Russia, China, Japan, Australia, South Africa, and Canada comparatively are better markets with less strict rules. The USA and EU import value-added products. It refers to the use of production methods, innovation and handling processes intended to improve the farmers' processes and products in order to lead to an enhancement in the processing, packaging, and marketing of the product.

The export market has three types of consumers- hotels/restaurants, institutional buyers and retailers. Large retailers like
Walmart, Redchamber, FAsfo, etc. buy directly. The USA market is a credit market. A container takes about 45 to 50 days to reach. After FDA clearance, the product reaches the stores. So, the working capital requirement is high, and thus companies with higher working capital can export to the USA market. The duration of remittance realisation is 60 to 70 days. A company exporting to the USA may thus have around $1 / 3$ rd of revenue outstanding. The export to Japan does not have a delay in payment, but, they prefer sea prawns for its purity. The cultured prawn export to Japan declined. Also, they perceive the Indian processing to be of inferior quality, and they usually import from China, Vietnam, Thailand and other South-East Asian countries which in turn import the raw prawn from India for value addition and re-export.

An analysis was carried out to find if the export growth is solely due to a decrease in the value of Indian currency (Table 2). The analysis is presented below. The quantity and value of marine product export data were taken from the Government of Odisha data (Annual Activity Report 2017-18, 2018), the exchange rate was taken from RBI Data (Reserve Bank of India, n.d.)

\begin{tabular}{|l|l|l|l|}
\hline \multicolumn{5}{c}{ Table 2: Export of Marine Products from Odisha } \\
\hline Year & Quantity (In MT) & Value (In INR Crores) & Exchange Rate \\
\hline $2000-01$ & 10644 & 379.09 & 45.68 \\
\hline $2001-02$ & 8062 & 279.00 & 47.69 \\
\hline $2002-03$ & 8448 & 246.20 & 48.39 \\
\hline $2003-04$ & 8344 & 223.20 & 45.95 \\
\hline $2004-05$ & 9539 & 241.20 & 44.93 \\
\hline $2005-06$ & 9804 & 259.39 & 44.27 \\
\hline $2006-07$ & 10521 & 304.46 & 45.24 \\
\hline $2007-08$ & 14161 & 351.52 & 40.26 \\
\hline $2008-09$ & 14135 & 357.88 & 45.99 \\
\hline $2009-10$ & 14588 & 421.06 & 47.44 \\
\hline $2011-11$ & 19725 & 606.41 & 45.56 \\
\hline $2012-13$ & 21078 & 792.76 & 47.92 \\
\hline $2013-14$ & 23691 & 908.48 & 54.40 \\
\hline $2014-15$ & 29479 & 1769.45 & 60.50 \\
\hline $2015-16$ & 32468 & 1963.85 & 61.14 \\
\hline $2016-17$ (P) & 35612 & 1791.81 & 65.46 \\
\hline Source: Government of Odisha data and RB| data & 67.07 \\
\hline
\end{tabular}

The data indicates that the export quantity has grown 8.93 per cent compounded annual 
The value of export has a CAGR of 11.6 per cent with base 2000-01, and 14.78 per cent with 2001-02 as the base year. The export value CAGR is higher compared to the quantity of export CAGR, and a possible reason could be due to value addition. The Indian currency has depreciated 2.43 per cent within these years.

\section{Traceability}

Traceability in aquaculture is compulsory. Earlier, the registration was done under the coastal regulation zone act. Now, Agricultural and Processed Food Products Export Development Authority (APEDA) registration is mandatory. When the prawn is bought for brooding, and released in a pond, the production details from a specific pond have to be documented and shared. Before harvesting, a sample is collected and tested in the laboratory approved by Export Inspection Council (EIC) for the presence of antibiotics. The test certificate is necessary for export clearance. In case of failures, the production license is withdrawn, and the company is prohibited from further prawn farming.

\section{Suppliers of Plant Equipment}

The plant equipment suppliers are locally available. The refrigeration equipment for a large size plant with an investment of more than INR 700 million can be imported from Denmark, China or Vietnam. Indian equipment suppliers with similar technology levels are also available. Usually, the suppliers are entrepreneurs who worked abroad in the industry. However, fish or prawn importers usually enquire about the supplier of plant and machinery and have a preference if imported equipment is used. Importers may inspect at times as well. Plant equipment needs overhaul once each two years. The FDA team in India inspects the plant periodically. The products from FDA approved plants get exported without much scrutiny. All the containers from the non-FDA approved plant are checked, and the risk of rejection is high.

\section{Manufacturers and Exporters from Odisha}

The marine products exports development authority under the Ministry of Commerce and Industry indicates 44 organisations listed under different categories from Odisha (2017). The type of organisation indicates two manufacturers, 16 manufacturer exporters, 11 merchants, and 15 merchant exporters (Table 3). The directory has a total of 1212 organisations listed (The Marine Products Exporters Directory, 2017).

\section{Deras Food Park, Bhubaneswar}

The seafood park in Deras, Bhubaneswar was established to promote the seafood industry in Odisha along with the assistance from the Government of India. The state government acquired the land and developed the park. The price is much higher than the land price available from private parties. Many of the existing business thus have not acquired land in the food park. A letter from the state government indicated that the land would be allocated to others if people in business from Odisha do not show interest. Many contested that the land price was not viable and stayed away. Efforts to convince different Government agencies also went in vain. Few companies took private land in Balasore (about $200 \mathrm{Km}$ or 124 miles away) to have a large factory. The industry association pleaded with the central government, which directed the State to complete promised infrastructure before the further release of funds, stressing the expenditure and infrastructure creation to be audited and be transparent.

Press reports indicate that the seafood park has now received investment proposals of INR 4660 million from 20 different companies. It is estimated that the park will process 90,860 tonnes per annum (tpa) of seafood and generate 7,214 jobs. Falcon Marine Exports, Magnum Seafoods, Utkal Exports, and Vizag-based Coastal Corporation are some of the companies who have already committed investments (Dash, 2017; Rs 466 cr investment proposals for Deras Seafood Park, 2017). 


\begin{tabular}{|c|c|c|}
\hline & Organisation Name & Location - Process Type: Variety and Product, capacity \\
\hline 1 & $\begin{array}{l}\text { Alashore Marine } \\
\text { Exports }\end{array}$ & Balasore- Frozen: Seafood: Shrimp \\
\hline 2 & Padmashree Export & Khurda- Seafood: Shrimp \\
\hline 3 & $\begin{array}{l}\text { Balasore Marine } \\
\text { Exports }\end{array}$ & Balasore - Frozen: Seafoods: Shrimps, Fish, Cephalopods \\
\hline 4 & BB Estates \& Exports & $\begin{array}{l}\text { Bhubaneswar-Shrimps, Fish, Cephalopods; } 14 \text { tons per day } \\
\text { (TPD) }\end{array}$ \\
\hline 5 & Bijaya Marine Products & Puri - Frozen Seafood: Fish, Shrimps; 12.0 TPD \\
\hline 6 & Falcon Marine Exports & Bhubaneswar - Seafood: Shrimps, Fish; 106.2 TPD \\
\hline 7 & K R Enterprise & Bhubaneswar- Seafood: Shrimps, Fish; 29 TPD \\
\hline 8 & Kar Exports & Bhubaneswar- Capacity: 10 TPD \\
\hline 9 & Mahalaxmi Exports & Puri \\
\hline 10 & $\begin{array}{l}\text { Rams Assorted Cold } \\
\text { Storage Ltd }\end{array}$ & Bhubaneswar- Seafood: Shrimps \\
\hline 11 & $\begin{array}{l}\text { S Chanchala Combines } \\
\text { Pvt Ltd }\end{array}$ & Puri -Seafood: Shrimps, Fish, Cephalopods; 20.5 TPD \\
\hline 12 & Seagold Overseas & $\begin{array}{l}\text { Bhubaneswar- Fish, Shrimp, Squid, Cuttlefish: Frozen } \\
\text { Shrimps-HI Blocks \& IQF }\end{array}$ \\
\hline 13 & Shiva Exports & Bhubaneswar- Seafood, Shrimp \\
\hline 14 & $\begin{array}{l}\text { Shiva Frozen Food } \\
\text { Exports }\end{array}$ & Bhubaneswar- Shrimp: Shrimps \\
\hline 15 & Sreeragam Exports & Bhubaneswar- Frozen: Seafoods: Shrimps; 23.6 TPD \\
\hline 16 & Teekay Marines & $\begin{array}{l}\text { Bhubaneswar- Frozen \& IQF, Seafood: Shrimps, Fish, } \\
\text { Cephalopods; } 40 \text { TPD }\end{array}$ \\
\hline 17 & Utkal Exports & Bhubaneswar- Frozen: Seafoods: Shrimps, Fish; \\
\hline 18 & Magnum Sea Foods & Bhubaneswar- Seafood: Shrimps, Fish \\
\hline
\end{tabular}

\section{Contribution of the Industry and Challenges}

The existing businessmen of the state have contributed significantly to promote aquaculture. The exports jumped from USD 144.20 (2012-13) to 332.25 (2016-17) million (Annual Activity Report 2017-18, 2018). The state government coined slogans from 2000 to 20000 to highlight the achievements (Government of Odisha, 2018). This sector with high potential requires support. The coastal areas of the state do not have an industry to generate employment. Aquaculture is the next best option after agriculture. In few states, the government facilitates discussion among road construction and electricity departments, manufactures of feed, minerals, vitamins, and factory owners to arrive at an amicable solution, which helps the industry, survive and flourish.

This industry is generally impacted by natural disasters, climatic changes and diseases. Floods help in fish growth. Coastal Odisha is prone to floods and thus has its advantages. However, sometimes deficient rainfall leads to water scarcity and floods thus become unpredictable. There are a few other challenges, as discussed in this section.

\section{Land for Farming}

With the growth in the industry, suitable land for prawn farming becomes crucial. Such lands being in the remote areas are usually encroached by people and small prawn farmers 
as well. With the growth, there is a dearth of suitable large land bank for prawn culture.

\section{Role of Banks}

The banks do not finance, and insurance companies do not cover the risk of this business. From seeding to harvesting in 8 to 10 ponds, the working capital requirement is about INR 5 million. Few banks had earlier given loans for BT Prawn which became irrecoverable nonperforming assets (NPAs). After the reduction of the sea catch, the prawn culture was necessary to ensure a steady supply to the factory for production. Only a few with surplus funds could continue.

\section{Acceptance of Industry}

The industry has not gained public support. Once, a minister of the state had opposed a proposed seafood park in Bhadrak district with the pretext of bad smell around the prawn factory! The improved technology ensures no smell. The head of the prawn gets dipped in a chemical after beheading to prevent lousy smell during drying, and the body part goes for further processing. The attitude towards industry may influence its future adversely. Some coastal districts have the possibility to become large centres but needs the political will and public support.

\section{Value Addition and Labour}

Value-added processing will play an essential role in the growing aquaculture sector to help meet the demands of the consumer for safe, wholesome, high-quality seafood products. Odisha has hardly 4 to 5 of such plants. Only Falcon, Magnum and B-One have four modern plants.

The aquaculture industry has zero waste. Every part is useful and generates revenue. For drying of fish, solar heat is used. The fish head is grounded and stored for use as chicken feed, prawn feed, and even as Ayurvedic medicine. The class $C$ (lower grade) fish is enriched with Soya to improve protein content and also used as feed. It is exported to China.

The labours who behead prawn in the plant earn INR 4 per Kg as on today's (2018-19) standard.
On an average, labour can behead anywhere between $100 \mathrm{Kg}$ to $500 \mathrm{Kg}$ in 6 hours. The average harvest is 500-600 tons per day during the season per company. Thus, aquaculture creates entrepreneurship opportunities and scope for employment. The shell removal, scale removal, vein removal, cutting it to size, giving various designs (with tail / without tail), and other activities are labour intensive.

The value addition in aquaculture is broadly indicated in the areas of the level of safety, increase in shelf-life, level of quality, new market opportunities, and solution for supply chain issues. It is driven by technology. The concept of values-added as compared to value-added in aquaculture products indicates factors like environment-friendly, fair wages, empathetic treatment of workers, or humane treatment to the animals. Organisations such as the Marine Stewardship Council (MSC), Aquaculture Certification Council, and the Global Aquaculture Alliance are promoting evolving standards which go beyond the product itself (Morrissey, 2011).

\section{Fishing Ban}

There is a fishing ban between November to April each year for turtle conservation along the Paradeep coast, adversely impacting the livelihood of fishers (Nanda, 2017).

\section{Profitability}

At times, prawn farmers renege on the promise and sell in the market at higher prices, depriving the factory owner the raw materials. Factories of adjacent states also offer predatory prices to get the raw material. This practice affects sustainability, and local business people have to manage and control such practices. People in business indicate that loss is rare and less. The international market has different price level for different regions and the level of demand.

\section{Breeding}

Tiger Prawn brood can be caught from the sea. However, Vannamei brood is usually imported. Many times, the import restriction has prompted the local development of brood. It has met with limited success. 


\section{Future of the Industry}

All the members of the Odisha Seafood association are into farming. In 2018 seafood export from Odisha was INR 30000 million, a growth of 15 per cent. There are challenges like plant construction, giving the input materials and coordinating with local farmers. The advantage in case of Vannamei is that the input costs can be recovered if the disease is detected early and the excellent products can be harvested quickly. Initially, $70 \%$ of the total catch was from the sea, but now, $70 \%$ is from aquaculture. The cage culture for export variety fish is not yet adopted in Odisha. The global consumption of aquaculture fish is improving because of health benefits. Freezing technology is improving to ensure end-products without infection.

If the industry consolidates to a few monopolistic producers, the competitive characteristics that are imperative for industry growth might diminish.

\section{Conclusion}

This study aimed at reviewing aquaculture industry of Odisha, which continues to be a highly under-researched sector. Indeed, aquaculture is traditional as well as modern industry capable of generating revenue, foreign exchange, and employment. The current level of research on aquaculture industry of Odisha needs to be improved. Large freshwater and brackish water area in this coastal state, higher dependency on fisheries on livelihood, and yet a lower per capita fish consumption compared to the national per capita consumption, deserves a comprehensive investigation. A competitive domestic market positively influences the competitiveness in other markets. Thus, the competitive characteristics of the industry should be preserved and encouraged by the policy. Acquiring of scarce resources by incumbent firms may prevent further entry and make the industry monopolistic. The lack of any new firm after 2004 in the exporter's list is a possible indication of the same and warrants research. The efforts of existing players in valueadded and values-added products through technology adoption need research support.
This research indicates the entrepreneurial dynamics in this business sector since the 1970s and contributes to giving a historical perspective of the industry, highlighting its issues and challenges.

\section{References}

Anderson, J. L., Valderrama, D., \& Jorry, D. (n.d.). Shrimp Production Review. Retrieved from https://www.aquaculturealliance.org/wpcontent/uploads/2017/06/Day1_JimAnderson.p df

Annual Activity Report 2017-18. (2018).

Retrieved from

http://www.fardodisha.gov.in/sites/default/file s/pdfs/Annual Activity Report of Fisheries Sector 2017-18.pdf

APICOL. (n.d.). Fisheries. Retrieved from http://www.apicol.co.in/index.php/focussectors/fisheries

Dasgupta, S. (2018). Marine Food Exports / Media India Group. Retrieved, from https://mediaindia.eu/exports/marine-foodexports/

Dash, J. (2017, August 29). Odisha seafood park gets Rs $466 \mathrm{cr}$ investment proposals. Retrieved, from https://www.business-

standard.com/article/economy-policy/odishaseafood-park-gets-rs-466-cr-investmentproposals-117082900938_1.html

Fisheries and Animal Resources Development Department. (2014). Fishery Statistics.

Retrieved from

http://www.fardodisha.gov.in/?q=statistics/fish ery

Government of Odisha. (2018). Information on Brackish Water Sector and Seafood Exports from Odisha. Retrieved from http://fardodisha.gov.in/sites/default/files/misc /Seafood Exports from Odisha.PDF

History, Seafood Exporters Association of India. (n.d.). Retrieved, from http://seai.in/history/

India-Fish production volume in Odisha 2018. (n.d.). Retrieved from https://www.statista.com/statistics/735927/fis h-production-volume-odisha-india/ 
India Aquaculture Feed Market Growth, Trends, and Forecast (2018-2023). (n.d.). Retrieved from

https://www.mordorintelligence.com/industryreports/india-aquaculture-feed-market

Morrissey, M. T. (2011). Development of ValueAdded Products in Aquaculture. In M. G. CruzSuárez, L.E. Ricque-Marie, D. Tapia-Salazar, M. Nieto-López, D. A. Villarreal-Cavazos, \& L. Gamboa-Delgado, J. Hernández-Hernández (Eds.). Avances en Nutrición Acuícola XI Memorias del Décimo Primer Simposio Internacional de Nutrición Acuícola (pp. 12-27). México. Retrieved from https://www.uanl.mx/utilerias/nutricion_acuico la/XI/archivos/2-morriseymichael.pdf

Nanda, K. (2017). Odisha: Paradip fishing industry at doldrums, fishermen's association threatens stir - OdishaDiary. Retrieved from http://orissadiary.com/odisha-paradip-fishingindustry-doldrums-fishermens-associationthreatens-stir/

Odisha Fisheries Policy, 2015. (2015). Retrieved from

https://investodisha.gov.in/download/Odisha_F isheries_Policy_2015.pdf

Reserve Bank of India. (n.d.). Exchange rate of the Indian Rupee. Retrieved from https://rbidocs.rbi.org.in/rdocs/Publications/PD Fs/TABLE1483BFBEB5416E549A8AEE4F4BA7CD 270F3.PDF

Rs 466 cr investment proposals for Deras Seafood Park. (2017). Retrieved from https://www.dailypioneer.com/2017/stateeditions/rs-466-cr-investment-proposals-forderas-seafood-park.html
Scariah, K. ., Philipose, V., Dan, S. ., Nair, K. P., \& Subbaraman, G. (1987). An appraisal of the Marine Fisheries in Orissa. Cochin. Retrieved from https://core.ac.uk/download/pdf/33013671.pdf

The Marine Products Exporters Directory. (2017). Retrieved from https://www.mpeda.gov.in/MPEDA/exporterdirectory/index.html

Tietze, U. (1991). Marine Small-Scale Fisheries of Orissa: A general Description. Retrieved from http://www.fao.org/3/a-ae485e.pdf

Wolk, A. (2017). Potential health hazards of eating red meat. Journal of Internal Medicine, 281(2), 106-122.

https://doi.org/10.1111/joim.12543

\section{Conflict of Interest}

Authors report no potential conflict of interest.

\section{Acknowledgement}

Authors express their sincere gratitude to the anonymous reviewers. We also express our sincere appreciation to Ajay Kumar Dash, ExPresident, Seafood Exporters Association of India, Odisha region, Ramesh Mahapatra, Chairman Magnum Sea Foods, and Manoj Prusty, the promoter of Odisha Directory.

\section{Author Contribution Statement}

Brajaballav Kar: Conceptualisation, Interviews, primary and secondary data collection, draft preparation;

Sugato Tripathy: Secondary data collection, validation, editing and reviewing. 